\title{
Comparison of cheeses from goats fed 7 forages based on a new health index
}

\author{
D. Giorgio, ${ }^{1}$ A. Di Trana, ${ }^{1 *}$ M. A. Di Napoli, ${ }^{2}$ L. Sepe,${ }^{2}$ S. Cecchini,${ }^{3}$ R. Rossi, ${ }^{2}$ and S. Claps ${ }^{2}$ \\ ${ }^{1}$ School of Agricultural, Forestry, Food and Environmental Sciences, University of Basilicata, Potenza, Viale dell'Ateneo Lucano 10-85100, Italy \\ ${ }^{2}$ CREA Research Centre for Animal Production and Acquaculture, Bella Muro (PZ), S.S. 7 Via Appia-85051, Italy \\ ${ }^{3}$ Department of Sciences, University of Basilicata, Potenza, Viale dell'Ateneo Lucano 10-85100, Italy
}

\section{ABSTRACT}

This study proposed the General Health Index of Cheese (GHIC) as an indicator for the presence of health-promoting compounds in cheese and compared the antioxidant capacity and phenolic and fatty acid contents of cheeses from goats consuming 7 forage species. Ninety-one homogeneous Red Syrian goats were randomly assigned to 1 of 7 feeding treatments (Festuca arundinacea, Hordeum vulgare, Triticosecale, Pisum sativum, Trifolium alexandrinum, Vicia sativa, and Vicia faba minor). The housed goat groups received the scheduled forage ad libitum. Forage species affected the antioxidant capacity, the phenolic and fatty acid contents, the Health Promoting Index, and the GHIC. Trifolium alexandrinum, Triticosecale, and Hordeum vulgare showed a clear advantage in terms of beneficial fatty acids content in goat cheese. Cheese from the Triticosecale group also showed a high antioxidant capacity value even if its polyphenol content was intermediate compared with others. Trifolium alexandrinum and Triticosecale had the highest value of the new index GHIC. This comparison suggests that there are important differences in fatty acid profile and polyphenol content among cheeses from goats fed grasses and legumes commonly used in the Mediterranean area. In this first approach, GHIC index, which combines the positive components found in cheese, seems to be a useful tool to provide an indication concerning the general health value of the product.

Key words: General Health Index of Cheese, antioxidant capacity, phenolic content, fatty acid, forage species

\section{INTRODUCTION}

There is considerable interest in increasing levels of beneficial fatty acids (FA) and antioxidant compounds of dairy products with the overall aim of improving nu-

Received October 16, 2018.

Accepted April 12, 2019.

*Corresponding author: adriana.ditrana@unibas.it tritional quality and the long-term health of consumers. Polyunsaturated FA play an important role in the prevention and treatment of heart diseases (Simopoulos, 2008). With the aim of improving the FA composition of dairy products, many researchers are focusing their studies on the modification of ruminal microbial metabolism of FA through animal diet formulation (Savoini et al., 2016). However, most studies have focused on the use of fish oil, oilseeds, or rumen-protected or inert lipids in the diet to modify milk FA profile (Sampelayo et al., 2002), with much less attention paid to single forage species that represent the principal dietary component in extensive and semi-intensive systems (Bonanno et al., 2013). However, a high percentage of UFA makes products highly sensitive to oxidation. The presence of antioxidants could help prevent oxidation of milk FA. Additionally, increased antioxidants in milk may provide several health benefits to consumers, including protection against free radicals, which are able to oxidize biomolecules, leading to mutagenic changes, tissue damage, and cell death (Celi, 2011). The use of synthetic antioxidants was considered an efficient tool for reducing changes in functional, sensory, and nutritive values of milk, but their use has been restricted due to their low stability and their toxic and carcinogenic effects (Milos and Makota, 2012). Increasing consumer awareness of food additives and safety has increased interest in the use of antioxidants from natural sources, such as plant-derived polyphenols.

Phenolic compounds are widespread in the plant kingdom, and their effectiveness as dietary antioxidants in animal feeding has received considerable attention in the last decade (Vasta and Luciano, 2011). The presence of antioxidant compounds in dairy products has been observed after the intake of some forage species and aromatic plants, thus providing the possibility of enriching milk and cheese with bioactive molecules fed directly to animals (Sepe et al., 2011; García et al., 2014; Di Trana et al., 2015a).

An effect of feeding system on phenolic compounds and antioxidant capacity in goat milk, whey, and cheese was also observed in some studies (Hilario et al., 2010; Chávez-Servín et al., 2018). Furthermore, plant second- 
ary compounds, such as tannic polyphenols, can have an effect on the milk FA composition because of their bacteriostatic and bactericidal effects on rumen microbes and consequently on ruminal biohydrogenation (Vasta and Luciano, 2011).

Forage plants, such as grasses and legumes, play an essential role in goat feeding, representing a high proportion of the diet. Consequently, studies are required to assess whether commonly used Mediterranean forages can be a natural source of bioactive compounds, such as FA and polyphenols, which can be transferred directly or indirectly to animal products. In addition, no studies have simultaneously measured bioactive compounds, such as FA and polyphenols, and total antioxidant capacity in goat cheese.

Taking into account the above considerations and that structural differences were observed when crude polyphenolic compounds were added to the cheese, resulting in rough and granular structures (Han et al., 2011), the aim of this work was to evaluate and to compare the natural antioxidant capacity, phenolic content, and healthy FA profile of goat cheeses from animals fed 7 forages, 3 grasses, and 4 legumes. In the current study, we also identified for the first time a new index named the General Health Index of Cheese (GHIC) for classifying our products as a function of the bioactive fractions known to have beneficial effects on human health.

\section{MATERIALS AND METHODS}

\section{Location, Animals, and Diets}

The experiment was carried out at the experimental farm of the CREA Research Centre for Animal Production and Aquaculture, Bella Muro, located 360 $\mathrm{m}$ above sea level in the Basilicata region (Southern Italy), from late May to early June. During the experiment, the goats were managed according to European
Union guidelines for accommodation and care of experimental animals (European Commission, 2010) and a recommendation of the Commission of the European Communities (European Commission, 2007), CREA (Bella-Muro) authorization of Ministry of Health no. 037D8. Ninety-one Red Syrian goats were allotted into 7 homogeneous groups by live weight $(42 \pm 1.2 \mathrm{~kg}$ ), BCS (score of 2.3), milk production $(1.1 \pm 0.3 \mathrm{~kg} / \mathrm{d}$ ), and DIM (90 $\pm 4 \mathrm{~d})$. To have homogeneous animals for DIM, in September the goats were estrous synchronized and mated so that kidding occurred within the last week of February. The goats were randomly allocated to the 7 feeding treatments with forage species: tall fescue (Festuca arundinacea Schreb.), barley (Hordeum vulgare L.), triticale (Triticosecale Wittm.), pea (Pisum sativum L.), berseem ( Trifolium alexandrinum L.), common vetch (Vicia sativa L.), and fava bean (Vicia faba L., var. minor). The goats were housed in group pens (1 pen/group), received the scheduled forage ad libitum with no supplementation, and had access to water and salt blocks. The forage species were sown in the same area at the farm of CREA (Bella-Muro) and grown in the same pedoclimatic conditions. The forages were cut and administered to housed goats at the following phenological stages, which are commonly used for grazing animals: T. alexandrinum, V. faba minor, and V. sativa at bloom; Triticosecale and H. vulgare at milk waxy; P. sativum at early seed; and $F$. arundinacea at pre-earing. The forages were harvested daily, coarsely cut, and offered ad libitum. The chemical composition of the offered forages is shown in Table 1.

Each experimental period lasted $11 \mathrm{~d}$, with $8 \mathrm{~d}$ to allow the rumen to fully adapt to the forage and $3 \mathrm{~d}$ for sampling and data collection. During the last $3 \mathrm{~d}$ of the experimental period, daily forage intake was measured. The forage sampling was carried out 3 times, and each sample was collected in duplicate. A subsample was immediately frozen $\left(-80^{\circ} \mathrm{C}\right)$ and subsequently lyophilized before polyphenols and total antioxidant capacity

Table 1. Chemical composition of forage species (\% of DM)

\begin{tabular}{|c|c|c|c|c|c|c|c|}
\hline Item & \multicolumn{3}{|c|}{ Grasses } & \multicolumn{4}{|c|}{ Legumes } \\
\hline $\mathrm{CP}$ & 12.97 & 12.14 & 8.46 & 19.18 & 14.64 & 22.47 & 15.71 \\
\hline Ether extract & 0.97 & 2.30 & 1.18 & 1.34 & 0.87 & 2.09 & 1.30 \\
\hline Ash & 6.81 & 3.50 & 6.42 & 7.25 & 8.31 & 4.41 & 8.13 \\
\hline $\mathrm{ADL}$ & 5.84 & 2.95 & 6.75 & 2.45 & 6.99 & 1.43 & 5.80 \\
\hline $\mathrm{NFC}^{1}$ & 23.89 & 20.02 & 23.23 & 35.12 & 40.77 & 43.72 & 40.74 \\
\hline
\end{tabular}

${ }^{1} \mathrm{NFC}=100-(\% \mathrm{NDF}+\% \mathrm{CP}+\%$ ether extract $+\%$ ash $)$. 
analyses, and the remaining samples were stored at $-20^{\circ} \mathrm{C}$ for further analyses.

\section{Cheese-Making}

In the days of the experimental period, goats were milked using a pipeline milking machine and the bulk milk of each group was processed into goat cheese. Two or more caciotta cheeses (350-400 g) per group and day of sampling were manufactured using a smallscale manufacturing facility at the cheese factory of CREA (Bella-Muro). The flowchart of caciotta cheese is presented in Di Trana et al. (2015b). Briefly, raw whole milk was filtered and heated in a stainless vat to $37^{\circ} \mathrm{C}$. Liquid calf rennet was added to milk in the amount of $20 \mathrm{~mL} / 100 \mathrm{~kg}$ of milk. Coagulation took place approximately $20 \mathrm{~min}$ after the addition of calf rennet, and the curd was broken down until it reached the size of nut pieces. After draining off the whey, the curd was pressed into cylindrical and perforated molds and stewed at $37^{\circ} \mathrm{C}$ for $3 \mathrm{~h}$. After cooling to 4 to $6^{\circ} \mathrm{C}$, molded cheeses were dry salted for $3 \mathrm{~d}$. The average weight of the manufactured cheeses was as follows: F. arundinacea, $2.20 \mathrm{~kg} / \mathrm{d} ;$ H. vulgare, 0.820 $\mathrm{kg} / \mathrm{d}$; Triticosecale, $0.940 \mathrm{~kg} / \mathrm{d}$; P. sativum, $1.39 \mathrm{~kg} / \mathrm{d}$; T. alexandrinum, $1.23 \mathrm{~kg} / \mathrm{d} ;$ V. faba minor, $1.08 \mathrm{~kg} / \mathrm{d}$; and $V$. sativa, $1.48 \mathrm{~kg} / \mathrm{d}$. Cheese samples were collected after $20 \mathrm{~d}$ of ripening (at $10^{\circ} \mathrm{C}$ and $80 \%$ environmental humidity) and stored at $-80^{\circ} \mathrm{C}$ until chemical analyses. The chemical analyses were performed on each cheese in duplicate.

\section{Chemical Analysis of Forage and Cheese}

The chemical composition of forages was analyzed by NIRSystem 5000 (Foss Electric, Hillerød, Denmark; Table 1). The cheese samples were analyzed for chemical composition (DM, fat, and protein; Table 2) using the standard methods described by Di Trana et al. (2009).

\section{Total Phenolic Content in Forage and Cheese}

The polyphenol content in forage was extracted with water as suggested by Cecchini et al. (2014) with slight modifications. Briefly, $5 \mathrm{~g}$ of forage sample was extracted by soaking in $50 \mathrm{~mL}$ of water at room temperature $\left(20^{\circ} \mathrm{C}\right)$ for $48 \mathrm{~h}$ under gentle shaking. The extracts were centrifuged at $3,000 \times g$ for $20 \mathrm{~min}$ at $4^{\circ} \mathrm{C}$. The supernatants were collected and filtered progressively up to $0.45 \mu \mathrm{m}$ before concentrating them using a lyophilizator. Extract was suspended in the water at a concentration of $1 \mathrm{mg} / \mathrm{mL}$ before phytochemical analyses. The total polyphenol content of forage extracts was determined using the Folin-Ciocalteu method (ISO, 2005). Tannic

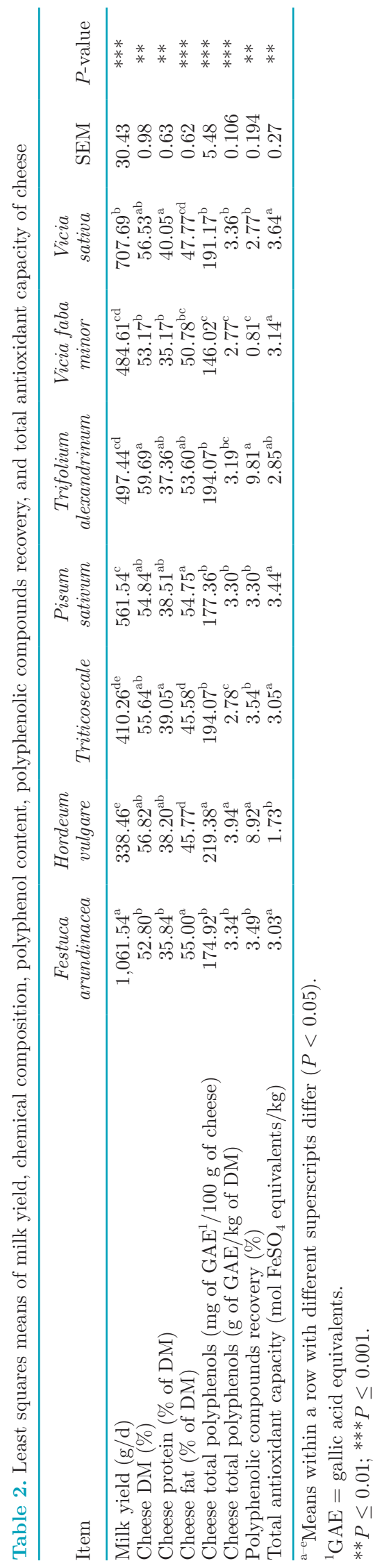


and nontannic polyphenol contents were determined using the Folin-Ciocalteu method after the addition of the insoluble matrix, polyvinylpolypyrrolidone, according to FAO/IAEA (2000). The total, nontannic, and tannic polyphenol contents were calculated from a standard curve using gallic acid as the standard, and results were expressed as milligrams of gallic acid equivalents (GAE) per gram of extracted sample.

Cheese total polyphenol (TP-C) was determined using the Folin-Ciocalteu colorimetric method after a methanolic extraction of sample according to the method of Rashidinejad et al. (2013) with slight modifications. Briefly, $500 \mathrm{mg}$ of grated cheese was homogenized for $1 \mathrm{~min}$ and extracted with $25 \mathrm{~mL}$ of solution of methanol (aqueous solution $95 \%$ ) and $\mathrm{HCl}(1 \%)$ for $30 \mathrm{~min}$ at $50^{\circ} \mathrm{C}$ under shaking $(200 \mathrm{rpm})$. The blend was cooled and filtered with a linen cloth, and the residue was washed with $1 \mathrm{~mL}$ of the same solution. Cheese total polyphenol was expressed as milligrams of GAE per 100 grams of sample.

\section{Antioxidant Capacity of Forage and Cheese}

Total antioxidant capacity of extract samples of cheese (TAC-C) and of forage was measured using the ferric ion reducing antioxidant power assay as indicated by Benzie and Strain (1996). The standard curve was constructed using iron sulfate heptahydrate $\left(\mathrm{FeSO}_{4} \cdot 7 \mathrm{H}_{2} \mathrm{O}\right)$. Data were expressed as mol $\mathrm{FeSO}_{4}$ equivalents per $\mathrm{kg}$ cheese and as $\mu M \mathrm{FeSO}_{4}$ equivalents for forage samples.

\section{FA Composition of Forage and Cheese}

Lipid fraction of forage was extracted from $20 \mathrm{~g}$ of forage sample using a mixture of chloroform and methanol (2/1 vol/vol) according to Gray et al. (1967). Lipid extract was methylated adding $1 \mathrm{~mL}$ of hexane and $0.05 \mathrm{~mL}$ of $2 N$ methanolic KOH (IUPAC, 1987).

Lipid fraction of cheese was obtained from cheeses samples thawed slowly at refrigerator temperature $\left(4^{\circ} \mathrm{C}\right)$ and finely grated. Three grams of grated cheese was extracted with chloroform and methanol mixture (2/1 vol/vol) according to Bligh and Dyer (1959). Lipid extract was methylated adding $1 \mathrm{~mL}$ of hexane and $0.05 \mathrm{~mL}$ of $2 \mathrm{~N}$ methanolic KOH (IUPAC, 1987).

Separation of the methyl esters in forage and cheese samples was performed according to Di Trana et al. (2004). Fatty acid methyl esters were identified with reference to the retention time of FA standard mixture of Supelco 37 Component FAME Mix (Supelco, Bellafonte, PA). The individual standard of CLA isomers (cis-9,trans-11 97\% and trans-10,cis-12 3\%) and C18:1 trans-11 standard were obtained from Larodan (Solna,
Sweden). The content of FA was quantified using internal standards (C9:0, C19:0, and C23:0; Supelco) added during the methylation step. Briefly, $100 \mathrm{mg}$ of lipid extract was mixed with $50 \mu \mathrm{L}$ of $2 N$ methanolic $\mathrm{KOH}$ and $1 \mathrm{~mL}$ of hexane containing the internal standards (20 mg/mL).

\section{Nutritional Indexes}

The Health Promoting Index (HPI) was calculated as suggested by Chen et al. (2004): (n-3 PUFA + n-6 PUFA + MUFA $) /[C 12: 0+(4 \times$ C14:0 $)+$ C16:0]. A new index, GHIC, was calculated to focus on both FA and antioxidant capacity of dairy products. The GHIC was calculated taking into consideration the following indicators: polyphenols, CLA isomers, PUFA, omega-3 FA, and total antioxidant capacity. In addition to CLA, PUFA, and omega-3, which are already known as health-promoting compounds, in GHIC calculation we used polyphenols and total antioxidant capacity because of their increasing health interest (O'Connell and Fox, 2001; Puchau et al., 2009). For each of the selected indicators, we defined minimum and maximum benchmarks, enabling us to rescale indicator values into scores between 0 (indicating a low health value) and 10 (indicating a high health value). In this first approach, the minimum and maximum values of these benchmarks were defined according to our data. For intermediate values, an increasing score of 1 was applied to each $5 \%$ increase of the value of the variable. For each cheese obtained from goats fed different forage species, we compared the value of each indicator with the minimum and maximum values of the scoring scale (Table 3). Then, the scores of the different indicators were summed for each cheese to obtain the GHIC.

\section{Statistical Analysis}

The data of FA composition were processed to compute the content of SFA, MUFA, PUFA, and UFA. The

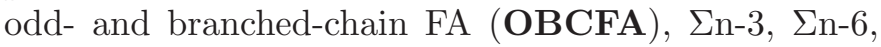
$\Sigma$ n-6/ $\Sigma$ n-3 ratios, C12:0/OBCFA, HPI, and GHIC were calculated. Statistical analysis of data was performed using the GLM procedure in Systat 13 (Systat Software Inc., Chicago, IL). The model included the feeding treatment with forage species ( $F$. arundinacea, H. vulgare, Triticosecale, P. sativum, T. alexandrinum, $V$. sativa, and $V$. faba minor) and day of cheese-making as fixed factors. No significant effect of day was observed. Mean comparison was tested by Tukey test. Pearson correlation coefficients were calculated among variables. Statistical differences were considered significant at $P \leq 0.05$. 


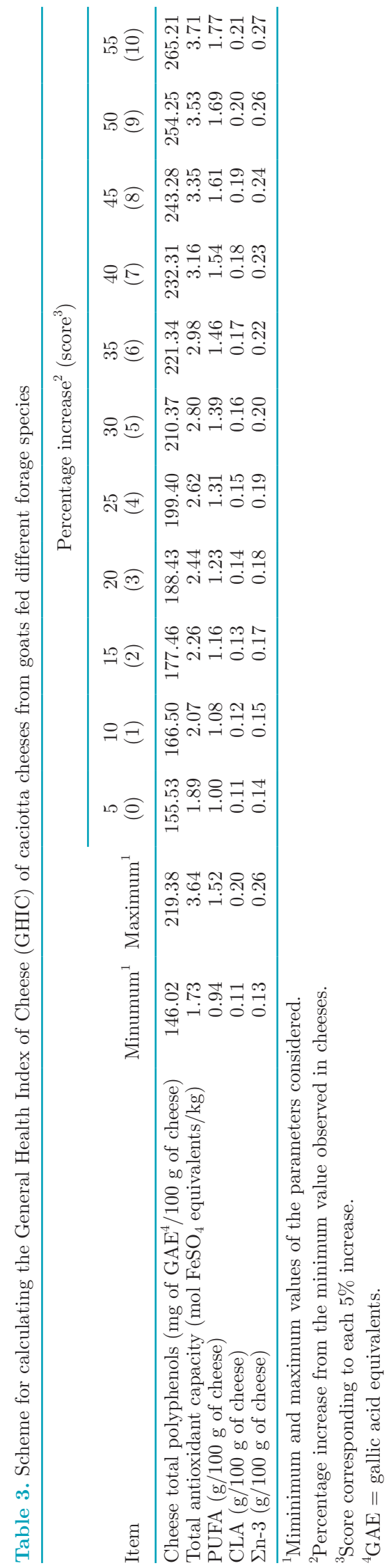

\section{RESULTS AND DISCUSSION}

\section{Cheese Characteristics}

The forage species significantly affected the chemical composition of cheese as shown in Table 2. Cheeses from T. alexandrinum exhibited a higher DM percentage (59.69\%) compared with $V$. faba minor and $F$. arundinacea cheeses (53.17 and $52.80 \%$, respectively). The highest fat percentage was observed in cheeses from goats fed F. arundinacea and P. sativum (55 and $54.75 \%$, respectively). Cheeses from V. sativa and Triticosecale showed a higher protein percentage (40.05 and $39.05 \%$, respectively) compared with $F$. arundinacea and $V$. faba minor cheeses (35.84 and $35.17 \%$, respectively). The goat cheese composition varied within the range usually observed for this type of cheese, which is produced in an artisanal way by a local cheese-maker using a small amount of bulk milk. Milk and cheese quality is a result of a complex process that is under the influence of many factors. Among them, the chemical composition, digestibility, and intake level of forage are the most important. Milk production depends on the level of intake, and fat content depends on the indirect effect of dilution; these aspects appear to be more important when diet included only 1 forage species and less important when several species were mixed (Morand-Fehr et al., 2007). In fact, goats are able to select their diet when more forage species are available and, as a consequence, to reduce the variations of energy and protein ingested daily.

\section{Total Phenolic Content}

Significant effects of the forage species were found for cheese total polyphenol $(P<0.001)$ and polyphenolic compounds recovery $(P<0.01$; Table 2$)$. Cheese from milk of goats fed $H$. vulgare exhibited the highest value of TP-C (3.94 g of GAE $/ \mathrm{kg}$ of DM). Compared with the $H$. vulgare cheese, in grasses polyphenols decreased $15.2 \%$ for $F$. arundinacea and $29.4 \%$ for Triticosecale, and in legumes decreased $14.7 \%$ for $V$. sativa, $16.2 \%$ for P. sativum, $19.0 \%$ for T. alexandrinum, and $29.7 \%$ for $V$. faba minor. The lowest TP-C content was found in cheese from goats fed $V$. faba minor $(2.77 \mathrm{~g}$ of GAE $/ \mathrm{kg}$ of DM). There were no significant differences between cheeses obtained from goats fed F. arundinacea, P. sativum, T. alexandrinum, and V. sativa.

Previous investigations have reported that the diet ingested by goats influences milk and cheese polyphenol content (Hilario et al., 2010; Sepe et al., 2011; Boutoial et al., 2013; Di Trana et al., 2015a; Chávez-Servín et al., 2018). Hilario et al. (2010) found an increase in total polyphenol content in goat milk and cheese obtained 
Table 4. Least squares means of polyphenol content ( $\mathrm{mg}$ of gallic acid equivalents $/ \mathrm{g}$ of extract), fatty acid content ( $\mathrm{g} / \mathrm{kg}$ of $\mathrm{DM}$ ), total antioxidant capacity $\left(\mu \mathrm{MFeSO}_{4}\right)$ of forage species, and intake (g/head per day)

\begin{tabular}{|c|c|c|c|c|c|c|c|c|c|}
\hline \multirow[b]{2}{*}{ Item } & \multicolumn{3}{|c|}{ Grasses } & \multicolumn{4}{|c|}{ Legumes } & \multirow[b]{2}{*}{ SEM } & \multirow[b]{2}{*}{$P$-value } \\
\hline & $\begin{array}{c}\text { Festuca } \\
\text { arundinacea }\end{array}$ & $\begin{array}{c}\text { Hordeum } \\
\text { vulgare }\end{array}$ & Triticosecale & $\begin{array}{l}\text { Pisum } \\
\text { sativum }\end{array}$ & $\begin{array}{c}\text { Trifolium } \\
\text { alexandrinum }\end{array}$ & $\begin{array}{l}\text { Vicia faba } \\
\text { minor }\end{array}$ & Vicia sativa & & \\
\hline \multicolumn{10}{|l|}{ Polyphenol content } \\
\hline Total polyphenols & $26.85^{\mathrm{b}}$ & $16.32^{\mathrm{c}}$ & $37.88^{\mathrm{a}}$ & $26.32^{\mathrm{b}}$ & $15.98^{\mathrm{c}}$ & $39.94^{\mathrm{a}}$ & $38.23^{\mathrm{a}}$ & 1.44 & $* * *$ \\
\hline Nontannic polyphenols & $23.34^{\mathrm{a}}$ & $12.70^{\mathrm{c}}$ & $11.64^{\text {cd }}$ & $18.77^{\mathrm{b}}$ & $8.98^{\mathrm{de}}$ & $6.11^{\mathrm{f}}$ & $6.53^{\text {ef }}$ & 0.49 & $* * *$ \\
\hline Tannic polyphenols & $3.51^{\mathrm{c}}$ & $3.62^{\mathrm{c}}$ & $26.24^{\mathrm{b}}$ & $7.55^{\mathrm{c}}$ & $6.92^{\mathrm{c}}$ & $33.83^{\mathrm{a}}$ & $31.70^{\mathrm{ab}}$ & 1.34 & $* * *$ \\
\hline इC14:0-C18:0 & $1.22^{\mathrm{c}}$ & $4.10^{\mathrm{a}}$ & $2.36^{\mathrm{b}}$ & $2.48^{\mathrm{b}}$ & $1.58^{\mathrm{c}}$ & $3.73^{\mathrm{a}}$ & $2.52^{\mathrm{b}}$ & 0.06 & $* * *$ \\
\hline $\mathrm{C} 16: 1$ cis & $0.19^{c}$ & $0.63^{\mathrm{a}}$ & $0.27^{\mathrm{c}}$ & $0.29^{\mathrm{b}}$ & $0.12^{\mathrm{c}}$ & $0.67^{\mathrm{a}}$ & $0.21^{\mathrm{c}}$ & 0.04 & *** \\
\hline$\Sigma C 18: 1$ cis-9 & $0.21^{\mathrm{de}}$ & $0.81^{\mathrm{b}}$ & $1.33^{\mathrm{a}}$ & $0.32^{\mathrm{d}}$ & $0.14^{\mathrm{e}}$ & $0.49^{\mathrm{c}}$ & $0.78^{b}$ & 0.02 & $* * *$ \\
\hline $\mathrm{C} 18: 2$ cis- 9, cis- 12 & $0.74^{\mathrm{c}}$ & $2.55^{\mathrm{a}}$ & $1.54^{\mathrm{b}}$ & $1.29^{\mathrm{bc}}$ & $1.11^{\mathrm{bc}}$ & $1.46^{\mathrm{bc}}$ & $1.68^{\mathrm{b}}$ & 0.17 & $* * *$ \\
\hline $\mathrm{C} 18: 3$ cis- 6, cis- 9, cis- 12 & $0.02^{\mathrm{bc}}$ & $0.02^{\mathrm{bc}}$ & $0.05^{\mathrm{a}}$ & $0.03^{\mathrm{ab}}$ & $0.01^{\mathrm{bc}}$ & $\mathrm{ND}^{1}$ & $0.00^{\mathrm{c}}$ & 0.001 & $* * *$ \\
\hline C18:3 cis-9,cis-12,cis-15 & $4.34^{\mathrm{bc}}$ & $7.53^{\mathrm{a}}$ & $2.66^{\mathrm{e}}$ & $4.74^{\mathrm{b}}$ & $3.06^{\text {de }}$ & $6.97^{\mathrm{a}}$ & $3.67^{\mathrm{cd}}$ & 0.19 & $* * *$ \\
\hline$\Sigma \mathrm{C} 20-\mathrm{C} 21$ & $0.17^{\mathrm{b}}$ & $0.31^{\mathrm{ab}}$ & $0.20^{\mathrm{b}}$ & $0.31^{\mathrm{ab}}$ & $0.19^{\mathrm{b}}$ & $0.43^{\mathrm{a}}$ & $0.30^{\mathrm{ab}}$ & 0.04 & $* *$ \\
\hline Nontannic polyphenols & $8.107^{\mathrm{a}}$ & $1.479^{\mathrm{d}}$ & $1.503^{\mathrm{d}}$ & $4.742^{\mathrm{b}}$ & $1.137^{\mathrm{e}}$ & $2.418^{\mathrm{c}}$ & $1.372^{\mathrm{d}}$ & 0.040 & $* * *$ \\
\hline Tannic polyphenols & $1.219^{\mathrm{e}}$ & $0.421^{\mathrm{g}}$ & $3.388^{\mathrm{c}}$ & $1.909^{\mathrm{d}}$ & $0.875^{\mathrm{f}}$ & $13.398^{\mathrm{a}}$ & $6.658^{\mathrm{b}}$ & 0.033 & $* * *$ \\
\hline
\end{tabular}

${ }^{\mathrm{a}-\mathrm{g}}$ Means within a row with different superscripts differ $(P<0.05)$.

${ }^{1} \mathrm{ND}=$ not detected.

${ }^{2} \mathrm{TAC}-\mathrm{F}=$ total antioxidant capacity in forage.

${ }^{*} P \leq 0.05 ;{ }^{* *} P \leq 0.01 ;{ }^{* * *} P \leq 0.001$.

from grazing animals compared with an indoor feeding system. Sepe et al. (2011) detected simple phenols in the cheese, milk, and whey of goats fed Avena sativa. Boutoial et al. (2013) showed that the introduction of nondistilled thyme leaves in goat diet increased cheese polyphenol content. Di Trana et al. (2015a) reported an increase in total polyphenol content in goat milk as a consequence of increased intake of Sulla coronarium L. fresh forage containing phenolic compounds. Recently, Chávez-Servín et al. (2018) observed an effect of feeding system (free-range grazing and permanent confinement) on phenolic compounds and antioxidant capacity in goat milk, whey, and cheese.

In our study, the differences observed in TP-C content could be ascribed to the polyphenolic profiles of forage species rather than the forage polyphenol content and daily forage intake (Table 4). In fact, the polyphenolic profiles of experimental forage species (Table 4) differ from each other in terms of total polyphenols, nontannic polyphenols, and tannic polyphenols. In addition, when plant extracts are used, it is possible to gain information on the effect of their constituent polyphenols as a group (nontannic and tannic polyphenols) but not on the digestive fate and specific effects of individual polyphenols. Unfortunately, in our study, the polyphenol qualitative profile was not investigated and we can only speculate about the similar polyphenol composi- tion between $H$. vulgare and $T$. alexandrinum. In the planning of subsequent studies, it would be advisable to investigate both the forage digestibility and polyphenolic profile.

It is known that the different polyphenolic profile of forages is closely associated with the different plant species, botanical family, environmental feature, period of harvesting, and their evolution when the plants grow older (Jeangros et al., 2001; Piluzza and Bullitta, 2010). In addition, the chemical and structural differences of plant polyphenols (i.e., molecular size, degree of polymerization of soluble and insoluble polyphenols, nature of the phenolic bind to other forage components; Bravo, 1998) result in a different bioavailability of these compounds in the rumen and gastrointestinal tract. The degradation and absorption of polyphenols within the rumen and the gastrointestinal tract depend both on the nature of the phenolic compound and on the rumen and intestinal microflora (Bravo, 1998), thus affecting the transfer of these bioactive molecules from animal diet to milk and cheese. Studying the effect of red clover on isoflavone concentration of goat milk, Sakakibara et al. (2004) found that these compounds moved to milk through some biotransformations. De Feo et al. (2006) demonstrated that the presence of phenolic compounds in milk depends on the animal feed and observed differences in polyphenolic profile between plant and milk; 
in fact, some plant metabolites were not found in milk. Every single forage, with its own phenolic profile, would seem to uniquely characterize the phenolic profile of goat milk.

To better compare the polyphenol content of cheeses in relation to forage species, the polyphenolic compound recovery in cheese was calculated on the basis of polyphenol daily intake by goats and those recorded daily in the cheeses (Table 2); these values ranged from $0.81 \%$ to 9.81\%. Hordeum vulgare cheese $(8.92 \%)$ and T. alexandrinum cheese $(9.81 \%)$ had the highest recovery values among grass and legume forages, respectively. A high recovery is considered desirable in the cheese-making process because a high value indicates a reduced loss of functional ingredients. The variability of the polyphenolic recovery seems to be related more to the nature and content of forage polyphenols than to forage intake (Table 4) among goat groups. The legumes $V$. faba minor and $V$. sativa show greater tannic polyphenol values compared with other legumes ( $P$. sativum, T. alexandrinum), and these values are 10 times higher than those found in grasses ( $F$. arundinacea and $H$. vulgare) with the exception of Triticosecale. The latter grass species exhibited the higher tannic polyphenol value compared with other grasses. Conversely, the nontannic polyphenol values were greater in forage grasses and lower in forage legumes with exception of $P$. sativum. Todaro et al. (2017) observed polyphenol recovery in Pecorino cheese that was 5 times higher in fresh lemon pulp diets than in the control diet without fresh lemon pulp. The recovery level of plant polyphenols in milk and cheeses could be linked to digestion; indeed, in ruminant animals, forage polyphenols are subject to a complex metabolism that involves the whole consortium of ruminal microorganisms. Studies on this topic could increase understanding of the interactions between the microbiome and forage polyphenols, to clarify their transfer in dairy products. On the other hand, the cheese-making process could affect cheese polyphenol content because of the solubility and polarity of phenolic compounds and their chemical interactions with milk proteins and fats (Han et al., 2011).

\section{Antioxidant Capacity}

The results obtained for the total antioxidant capacity of the forages and TAC-C are reported in Tables 2 and 4. Regarding forage species, higher values of antioxidant capacity were found in the legumes $V$. faba minor and $V$. sativa compared with the other forage species. Pearson correlation analysis showed that total antioxidant capacity of the forages was positively correlated with total polyphenols $(\mathrm{r}=0.66 ; P=0.056)$ and tannic polyphenols $(\mathrm{r}=0.76 ; P=0.048)$; these re- lationships are consistent with other reports (Dudonné et al., 2009). Some studies have demonstrated a linear positive correlation between the content of total phenolic compounds and antioxidant capacity (Kaur and Kapoor, 2002).

As shown in Table 2, experimental forage species affected the TAC-C $(P<0.01)$. The TAC-C in goat cheeses ranged from 1.73 to $3.64 \mathrm{~mol} \mathrm{FeSO}_{4}$ equivalents/ $\mathrm{kg}$. The higher values were found in $F$. arundinacea, Triticosecale, P. sativum, V. faba minor, and V. sativa cheeses (from 3.03 to 3.64 mol $\mathrm{FeSO}_{4}$ equivalents $/ \mathrm{kg}$ ) compared with cheese obtained from milk of goats fed $H$. vulgare $\left(1.73 \mathrm{~mol} \mathrm{FeSO}_{4}\right.$ equivalents $\left./ \mathrm{kg}\right)$. The $T$. alexandrinum cheese exhibited an intermediate value (2.85 $\mathrm{mol} \mathrm{FeSO}_{4}$ equivalents $/ \mathrm{kg}$ ). These TAC-C values are in agreement with those observed in goat cheese by Lucas et al. (2008), ranging between 2.09 and $13.4 \mathrm{~mol}$ $\mathrm{FeSO}_{4}$ equivalents $/ \mathrm{kg}$. These authors also reported an effect of the nature of the basic fodder ration on cheese antioxidant capacity. Few studies have evaluated the relationship between forage intake and levels of antioxidant activity in goat cheese and reported that grazing management positively affects goat cheese antioxidant activity, providing an increase in its total polyphenol concentration (Hilario et al., 2010; Chávez-Servín et al., 2018). Several milk compounds are antioxidants, such as uric acid, ascorbic acid, $\beta$-carotene, $\alpha$-tocopherol, phenols, whey protein, and casein (Fardet and Rock, 2018). It has been reported that microbial activity during cheese manufacturing and time of ripening could generate an increase in compounds having an effect on TAC in cheese (Lucas et al., 2006; Revilla et al., 2016). The TAC-C values are mainly influenced by the cheese-making process but independently of the type of cheese-making technology (Lucas et al., 2006). In our study TAC-C seem to be associated with the nature of the forage species and not with cheese-making process and time of ripening, which were the same for all cheeses. In goat cheese no significant correlation was found between TAC-C and TP-C, whereas a slight positive correlation was found between TAC-C and total polyphenols in plant $(\mathrm{r}=0.66 ; P=0.11)$. On the contrary, Rashidinejad et al. (2013) showed the contribution of the total phenolic content to the total antioxidant activity in low-fat hard cheese made with the addition of catechin. In addition, Di Trana et al. (2015a) found a positive correlation between milk polyphenols and milk TAC in goats fed increasing quantities of Sulla coronarium L. forage. The phytoderivatives added to the cheese during cheese-making (Rashidinejad et al., 2013) and the polyphenolic profile of the Sulla coronarium L. forage (Di Trana et al., 2015a) may have induced the different results compared with the results obtained in this present study. 


\section{FA Content}

The FA content of goat cheese was affected by forage plant species $(P \leq 0.001$; Table 5$)$. The important role of forage species, characterized by different FA content, and interactions between the nature of forage and oil supplements in modulating the FA composition of milk fat were reported previously for goats (Chilliard et al., 2003). Although the cheese FA composition reflects almost completely the milk FA composition (Nudda et al., 2005), results from the literature are largely focused on goat milk FA while information on FA content of cheese is scarce and needs further investigation. Besides, different technologies and ripening times make the comparison of cheese data from the literature difficult. In our study, the content of SFA was higher in cheese from goats fed $F$. arundinacea, P. sativum, T. alexandrinum, and Triticosecale than in cheese from other groups $(22.77,22.63,22.25$, and $22.00 \mathrm{~g} / 100 \mathrm{~g}$, respectively; $P \leq 0.05$ ). The highest SFA values were observed in cheeses with the highest fat content except for Triticosecale.

In our experimental conditions, in which goats in the fourth month of lactation received the scheduled forage without supplementation, the milk FA content (mainly MUFA and C18:1 cis-9; oleic acid, OA) is also linked to changes in energy balance of goats (Chilliard et al., 2003). When energy balance is negative, animals mobilize lipids stored in adipose tissues (rich in oleic, stearic, and palmitic acids), mainly in the form of nonesterified FA. This explains the $59 \%$ of the variability of milk C18:1 + C18:0 content (Bas et al., 1987). In our study, a negative energy balance seems to occur in the goats that produced cheeses with higher OA content (Triticosecale, T. alexandrinum, and H. vulgare groups) and that exhibited lower DMI and milk production compared with others. The higher OA content was observed in cheese fat from goats fed T. alexandrinum, H. vulgare, and Triticosecale compared with others. The highest linoleic acid (LA; C18:2 cis-9,cis-12) content was found in cheese fat from goats fed T. alexandrinum. Concerning linolenic acid (LNA; C18:3 cis-9,cis-12,cis-15), the higher values were detected in cheese fat from T. alexandrinum and Triticosecale groups. The nonendogenous fraction of OA together with LA and LNA derive from the diet (Palmquist, 2006); they are not synthesized by ruminant tissue, and their concentration in milk and consequently in cheese is dependent on their intake and on the amount that flows out of the rumen. In the present study, cheese from goats fed Triticosecale exibited higher OA, LA, and LNA $(6.12,0.51$, and $0.16 \mathrm{~g} / 100$ $\mathrm{g}$, respectively) than cheese from goats fed other grass

Table 5. Least squares means of fatty acid composition (g/100 g of cheese) and Health Promoting Index of goat cheeses from goats fed different forage species

\begin{tabular}{|c|c|c|c|c|c|c|c|c|c|}
\hline \multirow[b]{2}{*}{ Item } & \multicolumn{3}{|c|}{ Grasses } & \multicolumn{4}{|c|}{ Legumes } & \multirow[b]{2}{*}{ SEM } & \multirow[b]{2}{*}{$P$-value } \\
\hline & $\begin{array}{c}\text { Festuca } \\
\text { arundinacea }\end{array}$ & $\begin{array}{l}\text { Hordeum } \\
\text { vulgare }\end{array}$ & Triticosecale & $\begin{array}{l}\text { Pisum } \\
\text { sativum }\end{array}$ & $\begin{array}{c}\text { Trifolium } \\
\text { alexandrinum }\end{array}$ & $\begin{array}{l}\text { Vicia faba } \\
\text { minor }\end{array}$ & $\begin{array}{l}\text { Vicia } \\
\text { sativa }\end{array}$ & & \\
\hline SFA & $22.77^{\mathrm{a}}$ & $17.21^{\mathrm{c}}$ & $22.00^{\mathrm{a}}$ & $22.63^{\mathrm{a}}$ & $22.25^{\mathrm{a}}$ & $17.39^{\mathrm{c}}$ & $20.56^{\mathrm{b}}$ & 0.33 & $* * *$ \\
\hline MUFA & $4.54^{\mathrm{c}}$ & $6.25^{\mathrm{ab}}$ & $6.83^{\mathrm{a}}$ & $4.75^{\mathrm{c}}$ & $6.47^{\mathrm{a}}$ & $5.62^{\mathrm{b}}$ & $4.02^{\mathrm{c}}$ & 0.18 & $* * *$ \\
\hline PUFA & $1.04^{\mathrm{cd}}$ & $1.12^{\mathrm{c}}$ & $1.41^{\mathrm{b}}$ & $0.97^{\mathrm{de}}$ & $1.52^{\mathrm{a}}$ & $1.17^{\mathrm{c}}$ & $0.94^{\mathrm{e}}$ & 0.03 & $* * *$ \\
\hline C18:1 trans-11 & $0.03^{\mathrm{cd}}$ & $0.07^{\mathrm{b}}$ & $0.11^{\mathrm{a}}$ & $0.05^{\mathrm{bc}}$ & $0.03^{\mathrm{d}}$ & $0.02^{\mathrm{d}}$ & $0.07^{\mathrm{b}}$ & 0.001 & $* * *$ \\
\hline $\mathrm{C} 18: 1$ cis-9 & $3.99^{\mathrm{cd}}$ & $5.65^{\mathrm{ab}}$ & $6.12^{\mathrm{a}}$ & $4.78^{\mathrm{bc}}$ & $5.78^{\mathrm{a}}$ & $4.92^{\mathrm{bc}}$ & $3.77^{\mathrm{d}}$ & 0.22 & $* * *$ \\
\hline $\mathrm{C} 18: 2$ cis- 9, cis -12 & $0.46^{\mathrm{bc}}$ & $0.45^{\mathrm{c}}$ & $0.51^{\mathrm{bc}}$ & $0.49^{\mathrm{bc}}$ & $0.67^{\mathrm{a}}$ & $0.54^{\mathrm{b}}$ & $0.45^{\mathrm{c}}$ & 0.02 & $* * *$ \\
\hline $\mathrm{C} 18: 3$ cis-9,cis-12,cis-15 & $0.08^{\mathrm{c}}$ & $0.10^{\mathrm{c}}$ & $0.16^{\mathrm{ab}}$ & $0.13^{\mathrm{bc}}$ & $0.20^{\mathrm{a}}$ & $0.13^{\mathrm{bc}}$ & $0.12^{\mathrm{bc}}$ & 0.01 & $* * *$ \\
\hline $\mathrm{CLA}^{1}$ & $0.13^{\text {bd }}$ & $0.15^{\mathrm{bc}}$ & $0.16^{\mathrm{b}}$ & $0.13^{\text {bd }}$ & $0.20^{\mathrm{a}}$ & $0.12^{\text {cd }}$ & $0.11^{\mathrm{d}}$ & 0.01 & $* * *$ \\
\hline $\mathrm{C} 14: 1$ cis/C14:0 & $0.04^{\mathrm{b}}$ & $0.05^{\mathrm{a}}$ & $0.05^{\mathrm{a}}$ & $0.02^{\mathrm{d}}$ & $0.03^{\mathrm{c}}$ & $0.04^{\mathrm{b}}$ & $0.03^{\mathrm{d}}$ & 0.00 & $* * *$ \\
\hline$\Sigma \mathrm{OBCFA}^{2}$ & $0.56^{\mathrm{d}}$ & $0.65^{\mathrm{c}}$ & $0.84^{\mathrm{a}}$ & $0.54^{\mathrm{d}}$ & $0.81^{\mathrm{a}}$ & $0.75^{\mathrm{b}}$ & $0.50^{\mathrm{d}}$ & 0.02 & $* * *$ \\
\hline $\mathrm{C} 12: 0 / \Sigma \mathrm{OBCFA}$ & $2.05^{\mathrm{b}}$ & $1.32^{\mathrm{c}}$ & $1.27^{\mathrm{ac}}$ & $2.33^{\mathrm{d}}$ & $1.29^{\mathrm{ac}}$ & $1.12^{\mathrm{a}}$ & $1.97^{\mathrm{b}}$ & 0.04 & $* * *$ \\
\hline$\Sigma \mathrm{n}-3^{3^{\prime}}$ & $0.13^{\mathrm{c}}$ & $0.18^{\mathrm{b}}$ & $0.26^{\mathrm{a}}$ & $0.14^{\mathrm{bc}}$ & $0.24^{\mathrm{a}}$ & $0.18^{\mathrm{b}}$ & $0.15^{\mathrm{bc}}$ & 0.01 & $* * *$ \\
\hline$\Sigma n-6^{4}$ & $0.59^{\mathrm{c}}$ & $0.61^{\mathrm{c}}$ & $0.80^{\mathrm{a}}$ & $0.58^{\mathrm{c}}$ & $0.85^{\mathrm{a}}$ & $0.70^{\mathrm{b}}$ & $0.56^{\mathrm{c}}$ & 0.02 & $* * *$ \\
\hline$\Sigma n-6 / \Sigma n-3$ & $4.59^{\mathrm{a}}$ & $3.57^{\mathrm{bc}}$ & $3.09^{c}$ & $4.05^{\mathrm{ab}}$ & $3.53^{\mathrm{bc}}$ & $3.97^{\mathrm{ab}}$ & $3.65^{b c}$ & 0.14 & $* * *$ \\
\hline $\mathrm{HPI}^{5^{\prime}}$ & $0.43^{\text {de }}$ & $0.68^{\mathrm{a}}$ & $0.57^{\mathrm{b}}$ & $0.41^{\mathrm{de}}$ & $0.51^{\mathrm{c}}$ & $0.46^{\mathrm{d}}$ & $0.37^{\mathrm{e}}$ & 0.01 & $* * *$ \\
\hline
\end{tabular}

\footnotetext{
${ }^{\mathrm{a} e}$ Means within a row with different superscripts differ $(P<0.05)$.

${ }^{1}$ CLA contains a mixture of 2 isomers: $97 \%$ cis- 9 ,trans- 11 and $3 \%$ trans-10, cis- 12 .

${ }^{2}$ Odd- and branched-chain fatty acids ( OBCFA) are Eiso-C13:0 + anteiso-C13:0 + iso-C14:0 + iso-C15:0 + anteiso-C15:0 + C15:0 + iso-C16:0 + iso-C17:0 + anteiso-C17:0 + C17:0.

${ }^{3} \Sigma \mathrm{n}-3=\alpha-\mathrm{C} 18: 3+\mathrm{C} 20: 3$ cis-11,cis-14,cis-17 + C22:5 cis-7,cis-10,cis-13,cis-16,cis-19 + eicosapentaenoic acid + docosahexaenoic acid.

${ }^{4} \mathrm{n}-6=\mathrm{C} 18: 2$ cis-9,cis-12 + $-\mathrm{C} 18: 3+\mathrm{CLA}$ trans-10,cis-12 + C20:2 cis-11,cis-14 + C20:3 cis-8,cis-11,cis-14 + C20:4 cis-5,cis-8,cis-11,cis-14 + C22:4n-6 cis-7, cis-10, cis-13, cis-16.

${ }^{5}$ Health Promoting Index.

$* * * P \leq 0.001$.
} 
plant species. These results are in agreement with the high level of OA and LA observed in Triticosecale forage (Table 4: 1.33 and $1.54 \mathrm{~g} / \mathrm{kg}$ of DM, respectively). Among legume groups, T. alexandrinum cheese showed higher content of OA, LA, and LNA $(5.78,0.67$, and $0.20 \mathrm{~g} / 100 \mathrm{~g}$, respectively) compared with cheese from other legume species; however, a high level of OA and LA was not found in $T$. alexandrinum forage. The present results may be linked to the complex pathway involving different forage constituent such as plant FA and plant secondary metabolites. The FA profile of milk and cheese is not always directly linked to the forage FA profile; in fact, some studies have highlighted a more complex mechanism that involves the endogenous lipolysis, plant secondary metabolites (e.g., phenols and tannins), and plant polyphenol oxidase enzyme in ruminal biohydrogenation (Cabiddu et al., 2014; Lee, 2014) and different transfer efficiency of dietary FA in milk and cheese fat (Dewhurst et al., 2006). Interactions between polyphenol oxidase, plant secondary metabolites and their profile, endogenous lipolysis, and PUFA biohydrogenation need further study related to forage species. In cheese from goats fed T. alexandrinum, the higher value of PUFA $(1.52 \mathrm{~g} / 100 \mathrm{~g} ; P \leq 0.05)$ was linked to the higher cheese fat content.

The C18:2 cis-9,trans-11 isomer (rumenic acid) in milk fat and cheese has a duple origin: a small amount of rumenic acid escaping ruminal biohydrogenation and a major portion of rumenic acid appearing to originate from endogenous synthesis in the mammary gland from rumen-derived vaccenic acid by activity of $\Delta^{9}$-desaturase activity. Differences in concentrations of rumenic acid in milk fat observed in response to dietary treatments may also be explained by differences in $\Delta^{9}$-desaturase activity (Griinari and Bauman, 1999). The C18:2 trans10, cis-12 isomer seems to be exclusively synthesized in the rumen because the existence of a $\Delta^{12}$-desaturase in the mammary gland was not demonstrated (Griinari and Bauman, 1999). Both the cis-9,trans-11 and trans10, cis-12 CLA isomers appear to be active in inhibiting carcinogenesis in animal models (Pariza et al., 2001). In the current study, CLA contents are higher in cheese from goats fed T. alexandrinum compared with other legume groups $(0.20 \mathrm{~g} / 100 \mathrm{~g})$; in cheeses from goats fed grass, the CLA content was not significantly different. The variability of cheese vaccenic acid content (from 0.02 to $0.11 \mathrm{~g} / 100 \mathrm{~g}$ ) and CLA content (from 0.11 to $0.20 \mathrm{~g} / 100 \mathrm{~g}$ ) could be linked to the content of CLA precursors in plant species, their pathways of biohydrogenation, and $\Delta^{9}$-desaturase activity. In fact, C14: 1/C14:0 ratio, the best index of $\Delta^{9}$-desaturase activity (Impemba et al., 2007), ranged from 0.03 to 0.05 (Table $5)$.
The cheeses from goats fed Triticosecale and T. alexandrinum were also richer in OBCFA (0.84 and 0.81 $\mathrm{g} / 100 \mathrm{~g}$, respectively) than other groups. The highest value of OBCFA observed in cheese of Triticosecale was in accordance with the high level of NDF (Table 1), इC13:0, C15:0, C17:0 (data not shown), and low CP content of Triticosecale forage (Table 1), contributing to the synthesis of milk OBCFA. The OBCFA in milk fat are largely derived from rumen bacteria and could be useful noninvasive indicators of rumen fermentation as reported by Fievez et al. (2012). Indeed, the same authors reported that variations in milk OBCFA could reflect changes of rumen bacterial populations induced by diet composition. In accordance with our study, Povolo et al. (2012) found an effect of vegetation types of alpine pasture (Trifolium alpinum L. vs. Festuca nigrescens Lam) on OBCFA content in cow milk and cheese.

To verify whether classes of FA can discriminate the origin of cheeses on the basis of type of forage, different ratios between FA were studied. The ratio between C12:0, which originates from de novo synthesis in the mammary gland, and OBCFA was computed. Cheeses from goats fed $F$. arundinacea, P. sativum, and V. sativa showed higher values $(P<0.001)$ of $\mathrm{C} 12: 0 / \mathrm{OBCFA}$ ratio (range: 1.97-2.33) compared with other cheeses (range: $1.12-1.32$ ). This ratio provided to be a useful index to distinguish milk and cheese of cows of mountain and plains origins (Povolo et al., 2011).

A significant investigation indicates that excessive amounts of n-6 PUFA ( $\Sigma$ n-6) and a very high n-6/n-3 ratio $(\Sigma n-6 / \Sigma n-3)$, as is found in today's Western diets, promote the pathogenesis of many diseases, including cardiovascular disease, cancer, and inflammatory and autoimmune diseases (Simopoulos, 2008). As a consequence, opportunities to enhance omega-3 FA ( $\Sigma n-3)$ in many foods, including dairy products, are being explored. The optimal $\Sigma \mathrm{n}-6 / \Sigma \mathrm{n}-3$ ratio varies from $1 / 1$ to $4 / 1$ depending on the disease under consideration (Simopoulos, 2008). In the current study, cheeses from goats fed Triticosecale, T. alexandrinum, H. vulgare, and V. sativa showed a lower $\Sigma \mathrm{n}-6 / \Sigma \mathrm{n}-3$ ratio $(3.09,3.53$, 3.57 , and 3.65 , respectively) compared with others.

\section{Nutritional Indexes}

The health value of ruminant products can be improved by different dietary strategies to lower atherogenic FA, such as some SFA (C12:0, C14:0, C16:0), and favor beneficial PUFA with a particular emphasis on n-3 PUFA. The HPI was proposed by Chen et al. (2004) as an indicator of the health value of dietary fat. Dairy products with high HPI value are assumed to be more beneficial to human health. The relative proportion of 
FA having antiatherogenic (PUFA, CLA) and proatherogenic (SFA and trans FA) effects appears to vary in cheese fat, with consequent changes in HPI value. The effect of forage species on HPI value of milk was previously reported in goats fed 4 fresh forages (Avena sativa L., Lolium multiflorum Lam., T. incarnatum L., and Vicia sativa L.) and 1 silage forage (Triticosecale silage; Di Trana et al., 2009). In the current study, the highest HPI value of goat cheese was detected in the group fed $H$. vulgare (0.68), followed by the Triticosecale and $T$. alexandrinum groups ( 0.57 and 0.51 , respectively).

The presence of both FA and polyphenol compounds in cheese, derived or transformed from compounds of dietary origin, and antioxidant capacity of cheeses allows us to combine these variables to obtain a new index. Thus, the development of an index that takes into account the contribution of several bioactive components to the health value of the product could represent a valuable tool. Indeed, previous indexes mainly focused on the contribution of 1 component to the health value of the product (Chen et al., 2004; Pizzoferrato et al., 2007). The HPI index proposed by Chen et al. (2004) is largely focused on the effect of some FA on cardiovascular diseases. The degree of antioxidant protection, calculated by Pizzoferrato et al. (2007) as the molar ratio between an antioxidant compound and a selected oxidation target, evaluates goat cheese resistance to oxidative reactions. The GHIC, adopted for the first time in this study, combines in a single value the contribution of several components to animal product healthfulness (Figure 1). It allows the classification of our cheeses, simultaneously taking into account different indicators of human health. Similarly, Azzini et al. (2018) identified suitable and easily measurable indicators to assess the nutritional sustainability of several groups of foods. In the current study, the new index was significantly affected by forage species (Figure $1 ; P<0.01$ ). The highest value of GHIC was observed in cheese from goats fed Triticosecale (27.83) and T. alexandrinum (31.67), as expected because of their high polyphenol and beneficial FA contents. The GHIC values provide immediate information about the simultaneous presence of health-promoting compounds in cheese from goats fed Triticosecale and T. alexandrinum. However, in this paper we cannot define minimum and maximum literature values because of limited literature on this topic. Scientific papers that simultaneously analyze the antioxidant capacity and the FA and polyphenol contents in goat cheese (Lucas et al., 2006, 2008) are very few. As a consequence, in this first approach we

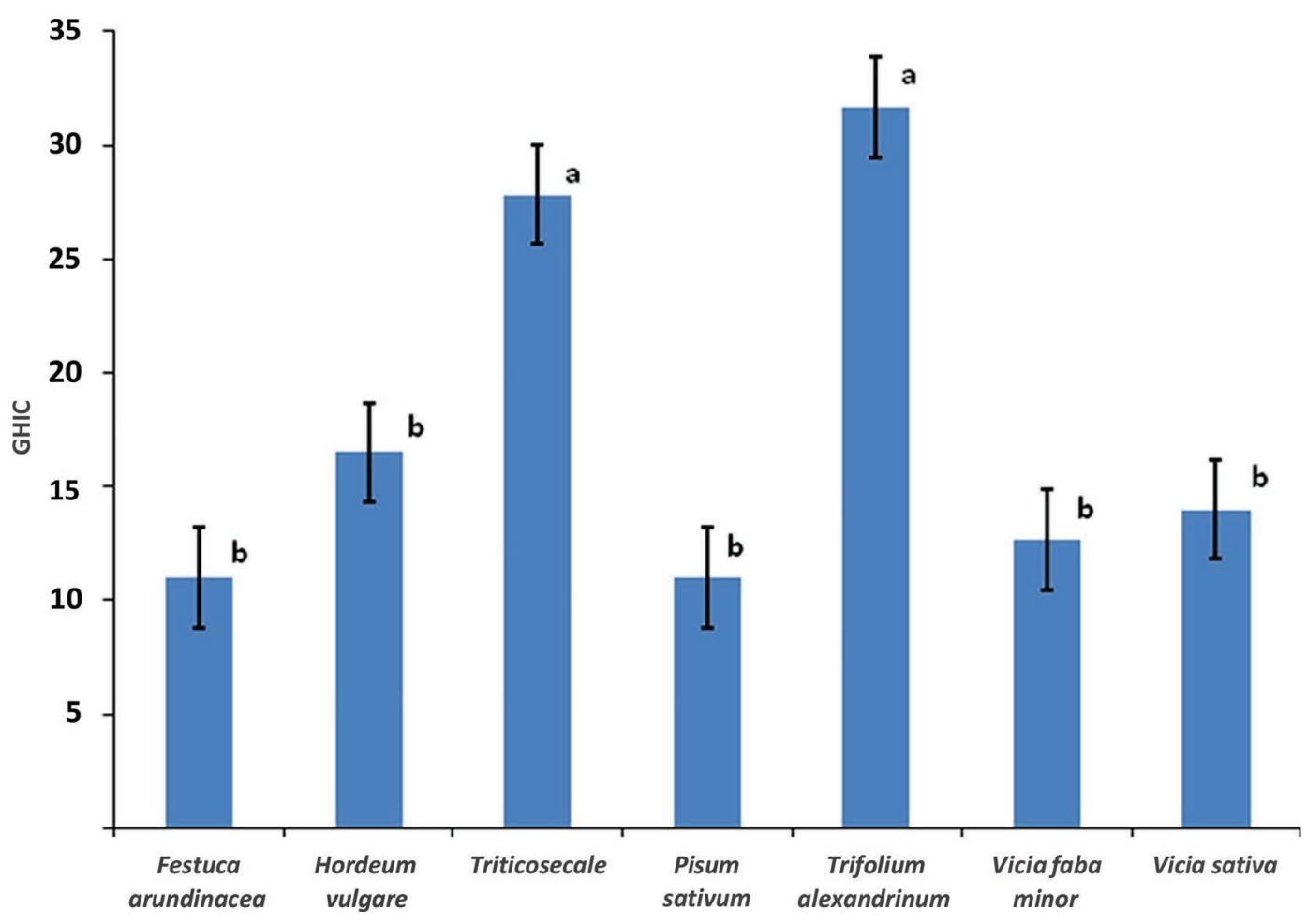

Figure 1. Comparison of General Health Index of Cheeses (GHIC) from goats fed different forage species. Results are presented as LSM \pm SEM. Different letters $(\mathrm{a}, \mathrm{b})$ indicate significant differences $(P<0.01)$ among cheeses. 
used the ranges recorded in this investigation. The next step will be to broaden our database to data currently available in the scientific literature.

\section{CONCLUSIONS}

These results suggest that the coexistence in every single forage species of a specific FA and polyphenol profile and their interactions during their digestive utilization unequivocally characterize dairy products. The GHIC index, which combines the positive components found in cheese, seems to be a tool to provide an indication concerning the health value of our products. The expansion of range margins of parameters considered in the GHIC would allow us to examine a wide type of cheeses and thus provide a global health indication. An adequate and planned use of forage species containing natural bioactive compounds could be a valid means to enhance dairy product quality by modulation of their FA and polyphenol profile without fat or antioxidant supplementation. Although in this study the animal and environment factors have been minimized, the chemical and health composition of the milk and cheese is a result of a complex mechanism in which the forage plays a strategic role that needs to be further explored.

\section{ACKNOWLEDGMENTS}

This research was supported by the project GRAZING funded by the University of Basilicata, Potenza, Italy $(102050101 / 17)$. This research was supported by the project IDENTILAT funded by the Italian Ministry of Agricultural, Food and Forestry Policies, Rome, Italy (MIPAAF; D.M.304/7303/05).

\section{REFERENCES}

Azzini, E., G. Maiani, A. Turrini, F. Intorre, G. Lo Feudo, R. Capone, F. Bottalico, H. El Bilali, and A. Polito. 2018. The healthnutrition dimension: A methodological approach to assess the nutritional sustainability of the typical agro-food products and the Mediterranean diet. J. Sci. Food Agric. 98:3684-3705.

Bas, P., Y. Chilliard, P. Morand-Fehr, A. Rouzeau, and N. Mandran. 1987. Composition des principaux tissus adipeux de la chèvre Alpine en fin de lactation. Ann. Zootech. 36:361-374.

Benzie, I. F., and J. J. Strain. 1996. The ferric reducing ability of plasma (FRAP) as a measure of "antioxidant power": The FRAP assay. Anal. Biochem. 239:70-76.

Bligh, E. G., and W. J. Dyer. 1959. A rapid method of total lipid extraction and purification. Can. J. Biochem. Physiol. 37:911-917.

Bonanno, A., A. Di Grigoli, A. Di Trana, P. Di Gregorio, G. Tornambè, V. Bellina, S. Claps, G. Maggio, and M. Todaro. 2013. Influence of fresh forage-based diets and $\alpha_{\mathrm{S1} 1}$-casein (CSN1S1) genotype on nutrient intake and productive, metabolic, and hormonal responses in milking goats. J. Dairy Sci. 96:2107-2117.

Boutoial, K., V. Garcìa, S. Rovira, E. Ferrandini, O. Abdelkhalek, and M. B. Lòpez. 2013. Effect of feeding goats with distilled and nondistilled thyme leaves (Thymus zygis subp. gracilis) on milk and cheese properties. J. Dairy Res. 80:448-456.
Bravo, L. 1998. Polyphenols: Chemistry, dietary sources, metabolism, and nutritional significance. Nutr. Rev. 56:317-333.

Cabiddu, A., M. R. F. Lee, M. Decandia, G. Molle, L. Salis, M. Vargiu, and A. L. Winters. 2014. Characterization of polyphenol oxidase activity in a range of forage ecotypes with different phenol substrates. A new insight for PPO and protein-bound phenol evaluation. Grass Forage Sci. 69:678-692.

Cecchini, S., M. Paciolla, A. R. Caputo, and A. Bavoso. 2014. Antioxidant potential of the polyherbal formulation "immuplus": A nutritional supplement for horses. Vet. Med. Int. 2014:434239.

Celi, P. 2011. Oxidative stress in ruminants. Pages 191-231 in Studies on Veterinary Medicine. Oxidative Stress in Applied Basic Research and Clinical Practice. L. Mandelker and P. Vajdovich, ed. Humana Press, Totowa, NJ.

Chávez-Servín, J. L., H. M. Andrade-Montemayor, C. V. Vázquez, A. A. Barreyro, T. García-Gasca, R. A. F. Martínez, A. M. O. Ramírez, and K. de la Torre-Carbot. 2018. Effects of feeding system, heat treatment and season on phenolic compounds and antioxidant capacity in goat milk, whey and cheese. Small Rumin. Res. 160:54-58.

Chen, S., G. Bobe, S. Zimmerman, E. G. Hammond, C. M. Luhman, T. D. Boylston, A. E. Freeman, and D. C. Beitz. 2004. Physical and sensory properties of dairy products from cows with various milk fatty acid compositions. J. Agric. Food Chem. 52:3422-3428.

Chilliard, Y., A. Ferlay, J. Rouel, and G. Lambere. 2003. A review of nutritional and physiological factors affecting goat milk synthesis and lipolysis. J. Dairy Sci. 86:1751-1770.

De Feo, V., E. Quaranta, V. Fedele, S. Claps, R. Rubino, and C. Pizza. 2006. Flavonoids and terpenoids in goats milk in relation to forage intake. Ital. J. Food Sci. 18:85-92.

Dewhurst, R. J., K. J. Shingfield, M. R. F. Lee, and N. D. Scollan. 2006. Increasing the concentrations of beneficial polyunsaturated fatty acids in milk produced by dairy cows in high-forage systems. Anim. Feed Sci. Technol. 131:168-206.

Di Trana, A., A. Bonanno, S. Cecchini, D. Giorgio, A. Di Grigoli, and S. Claps. 2015a. Effects of Sulla forage (Sulla coronarium L.) on the oxidative status and milk polyphenol content in goats. J. Dairy Sci. 98:37-46.

Di Trana, A., G. F. Cifuni, G. Impemba, A. Braghieri, S. Claps, and R. Rubino. 2004. The grazing system and season affect CLA, $\omega-3$ and trans fatty acid contents in goat milk. Prog. Nutr. 6:108-114.

Di Trana, A., L. Sepe, P. Di Gregorio, M. A. Di Napoli, D. Giorgio A. R. Caputo, and S. Claps. 2015b. The role of local sheep and goat breeds and their products as a tool for sustainability and safeguard of the Mediterranean environment. Pages 77-112 in The Sustainability of Agro-Food and Natural Resource Systems in the Mediterranean Basin. A. Vastola, ed. Springer International, Basel, Switzerland.

Di Trana, A., M. A. Di Napoli, S. Claps, L. Sepe, A. R. Caputo, and V. Fedele. 2009. Effect of feeding forage species on fatty acid profile of goat milk and cheese. Sci Tecn. Latt-Cas. 60:255-259.

Dudonné, S., X. Vitrac, P. Coutiere, M. Woillez, and J. M. Mérillon. 2009. Comparative study of antioxidant properties and total phenolic content of 30 plant extracts of industrial interest using DPPH, ABTS, FRAP, SOD, and ORAC assays. J. Agric. Food Chem. 57:1768-1774.

European Commission. 2007. Commission recommendation of 18 June 2007 on Guidelines for the accommodation and care of animals used for experimental and other scientific purposes. Off. J. Eur. Union. 197:1-89.

European Commission. 2010. Directive 2010/63/EU of the European Parliament and of the Council of 22 September 2010 on the protection of animals used for scientific purposes. Off. J. Eur. Union. 276:33-79

FAO (Food and Agriculture Organization of the United Nations)/ IAEA (International Atomic Energy Agency). 2000. Quantification of Tannins in Tree Foliage. IAEA, Vienna, Austria.

Fardet, A., and E. Rock. 2018. In vitro and in vivo antioxidant potential of milks, yoghurts, fermented milks and cheeses: A narrative review of evidence. Nutr. Res. Rev. 31:52-70. 
Fievez, V., E. Colman, J. M. Castro-Montoya, I. Stefanov, and B. Vlaeminck. 2012. Milk odd- and branched-chain fatty acids as biomarkers of rumen function-An update. Anim. Feed Sci. Technol. 172:51-65.

García, V., S. Rovira, K. Boutoial, and M. B. López. 2014. Improvements in goat milk quality: A review. Small Rumin. Res. 121:51-57.

Gray, I. K., M. G. Rumsby, and J. C. Hawke. 1967. The variations in linolenic acid and galactolipid levels in Graminaceae species with age of tissue and light environment. Phytochemistry 6:107-113.

Griinari, J. M., and D. E. Bauman. 1999. Biosynthesis of conjugated linoleic acid and its incorporation into meat and milk in ruminants. Pages 180-200 in Advances in Conjugated Linoleic Acid Research. Vol. 1. M. P. Yurawecz, M. M. Mossoba, J. K. G. Kramer, M. W. Pariza, and G. J. Nelson, ed. AOCS, Champaign, IL.

Han, J., M. Britten, D. St-Gelais, C. P. Champagne, P. Fustier, S. Salmieri, and M. Lacroix. 2011. Effect of polyphenolic ingredients on physical characteristics of cheese. Food Res. Int. 44:494-497.

Hilario, M. C., C. D. Puga, A. N. Ocana, and F. P. G. Romo. 2010. Antioxidant activity, bioactive polyphenols in Mexican goats' milk cheeses on summer grazing. J. Dairy Res. 77:20-26.

Impemba, G., G. F. Cifuni, and A. Di Trana. 2007. Influence of feeding system, stage of lactation and genetic types on $\Delta 9$-desaturase activity in caprine milk. Pages 147-152 in Advanced Nutrition and Feeding Strategies to Improve Sheep and Goat. A. Priolo, L. Biondi, H. Ben Salem, and P. Morand-Fehr, ed. CIHEAM, Zaragoza, Spain.

ISO (International Organization for Standardization). 2005. Determination of substances characteristic of green and black tea-Part 1: Content of total polyphenols in tea-Colorimetric method using Folin-Ciocalteu reagent. ISO method 14502-1. ISO, Geneva, Switzerland.

IUPAC. 1987. Standard Methods for the Analysis of Oils, Fats and Derivatives. Blackwell Scientific, Oxford, UK.

Jeangros, B., J. Scehovic, F. X. Schubiger, J. Lehmann, R. Daccord, and Y. Arrigo. 2001. Valeur nutritive des plantes des prairies 4. Composés phénoliques. Rev. Suisse Agric. 33:147-151.

Kaur, C., and H. C. Kapoor. 2002. Anti-oxidant activity and total phenolic content of some Asian vegetables. Int. J. Food Sci. Technol. 37:153-161.

Lee, M. R. F. 2014. Forage polyphenol oxidase and ruminant livestock nutrition. Front. Plant Sci. 5:694.

Lucas, A., J. B. Coulon, C. Agabriel, Y. Chilliard, and E. Rock. 2008. Relationships between the conditions of goat's milk production and the contents of some components of nutritional interest in Rocamadour cheese. Small Rumin. Res. 74:91-106.

Lucas, A., E. Rock, J. F. Chamba, I. Verdier-Metz, P. Brachet, and J. B. Coulon. 2006. Respective effects of milk composition and the cheese-making process on cheese compositional variability in components of nutritional interest. Lait 86:21-41.

Milos, M., and D. Makota. 2012. Investigation of antioxidant synergisms and antagonisms among thymol, carvacrol, thymoquinone and p-cymene in a model system using the Briggs-Rauscher oscillating reaction. Food Chem. 131:296-299.

Morand-Fehr, P., V. Fedele, M. Decandia, and Y. Le Frileux. 2007. Influence of farming and feeding systems on composition and quality of goat and sheep milk. Small Rumin. Sci. Res. 68:20-34.

Nudda, A., M. A. McGuire, G. Battacone, and G. Pulina. 2005. Seasonal variation in conjugated linoleic acid and vaccenic acid in milk fat of sheep and its transfer to cheese and ricotta. J. Dairy Sci. 88:1311-1319.
O'Connell, J. E., and P. F. Fox. 2001. Significance and applications of phenolic compounds in the production and quality of milk and dairy products: A review. Int. Dairy J. 11:103-120.

Palmquist, D. L. 2006. Milk fat: Origin of fatty acids and influence of nutritional factors thereon. Pages 43-92 in Advanced Dairy Chemistry. Vol. 2: Lipids. P. F. Fox and P. L. H. McSweeney, ed. Springer, Boston, MA.

Pariza, M. W., Y. Park, and M. E. Cook. 2001. The biologically active isomers of conjugated linoleic acid. Prog. Lipid Res. 40:283-298.

Piluzza, G., and S. Bullitta. 2010. The dynamics of phenolic concentration in some pasture species and implications for animal husbandry. J. Sci. Food Agric. 90:1452-1459.

Pizzoferrato, L., P. Manzi, S. Marconi, V. Fedele, S. Claps, and R. Rubino. 2007. Degree of antioxidant protection: A parameter to trace the origin and quality of goat's milk and cheese. J. Dairy Sci. 90:4569-4574.

Povolo, M., V. Pelizzola, and G. Contarini. 2011. Content of odd-and branched-chain fatty acids in milk and cheese of different origin. Ital. J. Anim. Sci. 10:1-138.

Povolo, M., V. Pelizzola, G. Lombardi, A. Tava, and G. Contarini. 2012. Hydrocarbon and fatty acid composition of cheese as affected by the pasture vegetation type. J. Agric. Food Chem. 60:299-308.

Puchau, B., M. Á. Zulet, A. G. de Echávarri, H. H. M. Hermsdorff, and J. A. Martínez. 2009. Dietary total antioxidant capacity: A novel indicator of diet quality in healthy young adults. J. Am. Coll. Nutr. 28:648-656

Rashidinejad, A., E. J. Birch, D. Sun-Waterhouse, and D. W. Everett. 2013. Effects of catechin on the phenolic content and antioxidant properties of low-fat cheese. Int. J. Food Sci. Technol. 48:2448-2455.

Revilla, I., M. I. González-Martín, A. M. Vivar-Quintana, M. A. Blanco-López, I. A. Lobos-Ortega, and J. M. Hernández-Hierro. 2016. Antioxidant capacity of different cheeses: Affecting factors and prediction by near infrared spectroscopy. J. Dairy Sci. 99:5074-5082.

Sakakibara, H., D. Viala, A. Ollier, A. Combeau, and J. M. Besle. 2004. Isoflavones in several clover species and in milk from goats fed clovers. Biofactors 22:237-239.

Sampelayo, M. S., L. Pérez, J. M. Alonso, L. Amigo, and J. Boza. 2002. Effects of concentrates with different contents of protected fat rich in PUFAs on the performance lactating Granadina goats: Part II. Milk production and composition. Small Rumin. Res. 43:141-148.

Savoini, G., G. Farina, V. Dell'Orto, and D. Cattaneo. 2016. Through ruminant nutrition to human health: Role of fatty acids. Adv. Anim. Biosci. 2:200-207.

Sepe, L., A. Cornu, B. Graulet, S. Claps, and D. Rufrano. 2011. Phenolic content of forage, milk, whey and cheese from goats fed $A v$ ena sativa. Pages 31-32 in Proc 10th International Meeting on Mountain Cheese, Dronero, CN, Italy. University of Turin, Turin, Italy.

Simopoulos, A. P. 2008. The importance of the omega-6/omega-3 fatty acid ratio in cardiovascular disease and other chronic diseases. Exp. Biol. Med. (Maywood) 233:674-688.

Todaro, M., M. Alabiso, M. L. Scatassa, A. Di Grigoli, F. Mazza, G. Maniaci, and A. Bonanno. 2017. Effect of the inclusion of fresh lemon pulp in the diet of lactating ewes on the properties of milk and cheese. Anim. Feed Sci. Technol. 225:213-223.

Vasta, V., and G. Luciano. 2011. The effect of dietary consumption of plant secondary compounds on small ruminants' product quality. Small Rumin. Sci. 101:150-159. 